Journal of Community Based Environmental Engineering and Management, 2021, Vol. 5, No. 1: 23-32

\title{
STRATEGY OF ECOREGION PROTECTION AND MANAGEMENT, CASE STUDY OF TASIKMALAYA CITY
}

\author{
Nurcholis Salman ${ }^{*}$ \\ Department of Environmental Engineering, Universitas Muhammadiyah Tasikmalaya, Indonesia
}

\begin{abstract}
The Tasikmalaya City Ecoregion Protection and Management Strategy is a planning study aimed to support other developments, in accordance with the mandate of Law Number 32 of 2009 concerning Environmental Protection and Management. The purpose of this document is to provide an indication of the policy direction for environmental protection and management plans in the Tasikmalaya City based on the results of an analysis of the main challenges and strategic issues that refer to an environmental inventory at the ecoregion level in the Tasikmalaya City. The preparation of this document is intended to provide direction, reference and basis for development in the Tasikmalaya City based on the potential, availability, limitations of ecosystem services and natural resources in the Tasikmalaya City which are manifested in the threshold and status of the carrying capacity and the carrying capacity of the environment. Based on this status, policy interventions and program directions for environmental management and protection can be further formulated as a controller of development in Tasikmalaya City. The study is structured through the following stages: (1) data collection, thematic maps, and related literature, (2) Situational Analysis for the formulation of the main challenges and strategic environmental issues in Tasikmalaya City, using a spatial analysis framework, followed by DPSIR analysis (Driving Forces-Pressure-State-Impacts-Response) to identify the root causes of strategic issues of environmental protection and management, formulate their impact on community welfare and formulate policies and program directions as interventions in environmental protection and management.
\end{abstract}

Keywords: ecoregion, sustainable development, Tasikmalaya City, DPSIR (Driving Forces-PressureState-Impacts-Response)

\section{Introduction}

An ecoregion is a geographical area that has the same characteristics of climate, soil, water, native flora and fauna, as well as patterns of human-nature interaction that reflect the integrity of natural systems and the environment (Bailey, 2005). In accordance with Article 7 paragraph (2) of Law 32 of 2009 concerning

${ }^{*}$ Corresponding Author:

E-mail: nurcholissalman@umtas.ac.id

Received: 13 February 2020

Revised: 16 February 2021

Accepted: 16 February 2021
Environmental Protection and Management, it is stated that the designation of ecoregion areas is carried out by taking into account the similarities:

a. Landscape characteristics;

b. Watershed;

c. Climate;

d. Flora and fauna;

e. Socio-cultural;

f. Economy;

g. Community institutions; and

h. Environmental inventory results. 
Ecoregion is understood as a land character that acts as a character trait and land potential constraints in accordance with its carrying capacity and carrying capacity. In the context of realizing sustainable development, Indonesia has established an ecoregion as a reference in the management and utilization of the environment. Ecoregion determination is the basis and has a very important role in seeing the linkages interactions, interdependencies and dynamics of the use of various natural resources between ecosystems in one ecoregion area (Ramadanta et.al, 2011). An ecoregion can be located within the volcanic mountain ecoregion of Mt. Halimun - G. Salak - G. Sawal stretching across the central part of West Java Province. One of the regions In addition, another goal of ecoregion designation is that functionally it can produce environmental protection-management planning, monitoring and evaluation together between interdependent regions, even though development operations are still carried out respectively by administrative regional offices, according to their respective authority (Subekti, 2016). Based on the Decree of the Minister of Environment and Forestry No.SK.8/ MENLHK/ SETJEN/ PLA.3/ 1/2018 concerning the Designation of Indonesian Ecoregions in Appendix I, the types of ecoregions in Tasikmalaya City include the ecoregion of the Mount Halimun-Mount Salak volcanic mountain complex. -Mount Sawal, the ecoregion of the Mount Ciremai volcanic mountain complex and the ecoregion of the Tasikmalaya karst hill complex. The area in Tasikmalaya City which is included in the ecoregion of the volcanic mountain complex G. Halimun - G. Salak - G. Sawal is Kawalu District, Tamansari District, Cibeureum District, Mangkubumi District, Cihideung District, Bungursari District, Indihiang District, and Cipedes District. Area of the ecoregion is $16,087 \mathrm{Ha}$.

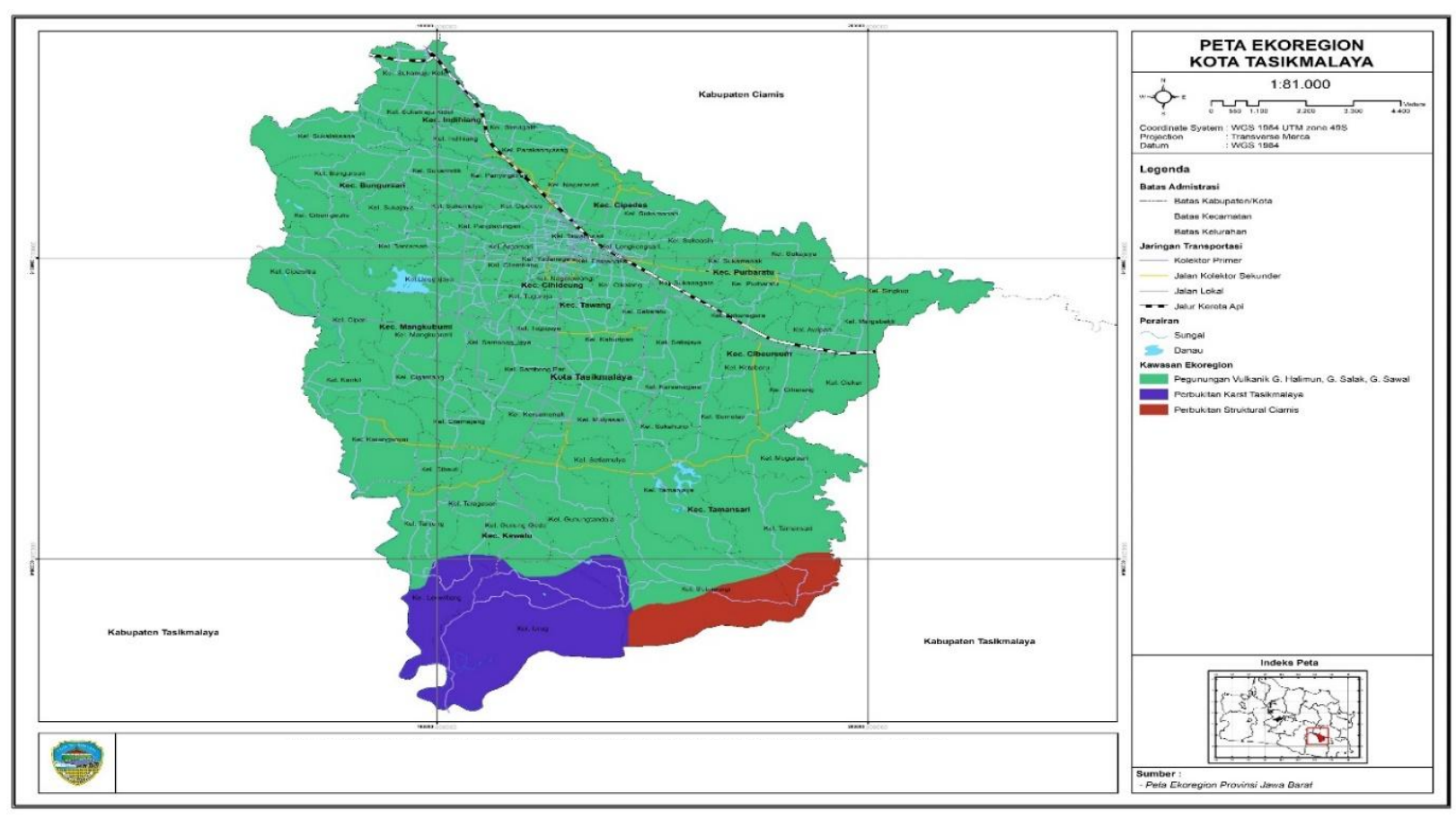

Figure 1. Ecoregion of Tasikmalaya City 


\section{Methodology}

The methodology used is the DPSIR (Driving Forces - Pressure - State - Impacts - Response) analysis from the European Environment Agency (2016) to identify the root causes of strategic issues of environmental protection and management, to then formulate their impact on community welfare and formulate policies and directions. Programs act as an intervention in environmental protection and management. The use of the DPSIR method is based on the consideration that it provides a framework for understanding indicators and responses to the impact of human activities on the environment by referring to the causal chain of: driving force - pressure - state - impact - response. In addition, this method is based on a comprehensive system analysis so that it can be used as an analytical tool oriented towards determining strategic policies (Carr et.al, 2007) (Wang et.al, 2015).

The stages of preparing RPPLH using the DPSIR analysis framework are as follows:

1. Collecting data and related literature, which includes but is not limited to:

a. Ecoregion Map at 1: 500,000 scale and its description book.

b. The document on the results of an analysis of ecosystem services for each ecoregion in order to determine the potential of an ecosystem's "goods" and "services" and determine the important ecosystem services for the island ecoregion.

c. Natural resources utilization evaluation analysis document.

d. Environmental carrying capacity and carrying capacity analysis documents.

e. Land Cover Map.

f. Maps related to natural resource utilization permits. g. Forest Area Map.

h. Disaster maps related to ecological damage.

i. Other thematic maps as needed.

2. Situational Analysis for the formulation of the main challenges and strategic environmental issues in the Tasikmalaya City. This stage is a comprehensive analysis of the characteristics of the area, environmental issues and problems and their respective locations. In detail, the stages include processing and analysis of data (spatial and non-spatial) to analyze the potential and facts of each ecoregion, as well as to consider development priority issues in Tasikmalaya City. Spatial data analysis at this stage includes:

a. Preparation of ecosystem service index map for each ecoregion of Tasikmalaya City.

b. Preparation of the threshold map and status of the Tasikmalaya DDLH, which consists of the preparation of:

- Map of availability of food stock and clean water.

- Map of the need for food stock and clean water

- Determination of the status of environmental carrying capacity based on food and water ecosystem services.

- Preparation of waste threshold and capacity maps.

- Compilation of emission distribution maps for air quality.

\section{Result and Discussion}

Projected Population Growth and Its Impact on Environmental Supporting Capacity

One of the causes of environmental pressure is population growth. In this plan, the pressure on the environment is analyzed based on the prediction of population growth, population density, and population distribution over the next 30 years starting from 2017 to 2028,2038 , 
and 2048. The analysis was carried out descriptively by looking at growth patterns and changing trends. land cover, and what ecosystem services are affected by the stress.

An increase in the population in an area will be followed by a change in land use from a green area to a built-up area in order to meet housing needs and basic infrastructure for residents. This puts pressure on the ecoregion area because of the reduced land for ecosystem sustainability which results in damage to the ecosystem and disruption of the structure and function of the ecosystem to produce ecosystem services optimally. On the other hand, population growth also results in increased demand for ecosystem services that produce food and water, resulting in additional burdens in the utilization of ecosystem services, which can have an impact on decreasing the carrying capacity of the environment for food and water.

Based on the projection results of population growth in 2017-2048, it is known that the population in Tasikmalaya City has experienced significant population growth and can affect land availability, especially food land. Table 1 shows the population projection.

Table 1. Estimated Population Growth of the City of Tasikmalaya in 2017-2048

\begin{tabular}{clccccc}
\hline \multirow{2}{*}{ No } & \multirow{2}{*}{ District } & \multicolumn{5}{c}{ Year (People) } \\
\cline { 3 - 7 } & & $\mathbf{2 0 1 7}$ & $\mathbf{2 0 1 8}$ & $\mathbf{2 0 2 8}$ & $\mathbf{2 0 3 8}$ & $\mathbf{2 0 4 8}$ \\
\hline 1 & Kawalu & 88,531 & 88,804 & 91,581 & 94,445 & 97,399 \\
\hline 2 & Tamansari & 66,084 & 66,310 & 68,614 & 70,998 & 73,465 \\
\hline 3 & Cibeureum & 66,149 & 66,952 & 75,530 & 85,206 & 96,123 \\
\hline 4 & Purbaratu & 39,458 & 39,589 & 40,930 & 42,317 & 43,750 \\
\hline 5 & Tawang & 65,679 & 66,000 & 69,294 & 72,753 & 76,384 \\
\hline 6 & Cihideung & 74,469 & 74,764 & 77,781 & 80,921 & 84,187 \\
\hline 7 & Mangkubumi & 88,957 & 89,304 & 92,850 & 96,538 & 100,372 \\
\hline 8 & Indihiang & 50,677 & 51,062 & 55,077 & 59,407 & 64,078 \\
\hline 9 & Bungursari & 47,784 & 47,970 & 49,878 & 51,861 & 53,923 \\
\hline 10 & Cipedes & 77,958 & 78,222 & 80,915 & 83,701 & 86,582 \\
\hline & Total & 827,916 & 868,993 & $1,410,313$ & $2,288,837$ & $3,714,619$ \\
\hline
\end{tabular}

From the table of population growth projections in Tasikmalaya City in 2017-2048, it is known that the population growth is quite significant, where the projected growth is carried out per 10 years. The highest population growth is Mangkubumi District with a population in 2028 reaching 92,850 people and in 2048 is 100,372 people from the total population in 2048 is $3,714,619$ people. While the lowest population growth is in Purbaratu District with a population in 2028 reaching 40,930 people and in 2048 is 43,750 people. An overview of the population growth projection can be seen on the population growth map and the attachment to the population projection in Tasikmalaya City.
The population density in Tasikmalaya City from the projection results is experiencing growth in line with the projected population growth. The total population density in 2017 is 4,503 people $/ \mathrm{km}^{2}$, while the total population density in 2048 is 20,205 people $/ \mathrm{km}^{2}$.

Table 2 shows the population density projections in Tasikmalaya City in 2017-2048, it is known that the highest population density is Cihideung District with the population density in 2018 reaching 13,618 people $/ \mathrm{km}^{2}$ and in 2048 it is 15,335 people $/ \mathrm{km}^{2}$. Meanwhile, the lowest population density is in Tamansari District with the total population density in 2018 reaching 1,842 people $/ \mathrm{km}^{2}$ and in 2048 it is 2,041 people $/ \mathrm{km}^{2}$. 
Table 2. Estimated of Total Population Density of the City of Tasikmalaya in 2017-2048

\begin{tabular}{clccccc}
\hline \multirow{2}{*}{ No } & \multirow{2}{*}{ District } & \multicolumn{5}{c}{ Year $\left(\right.$ People/ $\left./ \mathbf{k m}^{2}\right)$} \\
\cline { 3 - 7 } & & $\mathbf{2 0 1 7}$ & $\mathbf{2 0 1 8}$ & $\mathbf{2 0 2 8}$ & $\mathbf{2 0 3 8}$ & $\mathbf{2 0 4 8}$ \\
\hline 1 & Kawalu & 2,069 & 2,076 & 2,141 & 2,208 & 2,277 \\
\hline 2 & Tamansari & 1,836 & 1,842 & 1,906 & 1,973 & 2,041 \\
\hline 3 & Cibeureum & 3,474 & 3,516 & 3,967 & 4,475 & 5,048 \\
\hline 4 & Purbaratu & 3,283 & 3,294 & 3,405 & 3,521 & 3,640 \\
\hline 5 & Tawang & 9,277 & 9,322 & 9,787 & 10,276 & 10,789 \\
\hline 6 & Cihideung & 13,564 & 13,618 & 14,168 & 14,740 & 15,335 \\
\hline 7 & Mangkubumi & 3,626 & 3,641 & 3,785 & 3,936 & 4,092 \\
\hline 8 & Indihiang & 4,590 & 4,625 & 4,989 & 5,381 & 5,804 \\
\hline 9 & Bungursari & 2,826 & 2,837 & 2,950 & 3,067 & 3,189 \\
\hline 10 & Cipedes & 8,691 & 8,720 & 9,021 & 9,331 & 9,652 \\
\hline & Total & $\mathbf{4 , 5 0 3}$ & $\mathbf{4 , 7 2 7}$ & $\mathbf{7 , 6 7 1}$ & $\mathbf{1 2 , 4 5 1}$ & $\mathbf{2 0 , 2 0 5}$ \\
\hline
\end{tabular}

\section{Conflict on the Natural Resources Utilization}

Land use conflicts are still one of the main problems in environmental management, especially in developing countries (Magsi et.al, 2017). An overlap in the location of utilization between natural resources can cause environmental damage, especially if the utilization is not taking into account the ecological functions or ecosystem services in an area. Table 3 is an indication of the overlapping use of natural resources in the agriculture, forestry, energy and water resources sectors in the Tasikmalaya City, among others.

Table 3. Overlapping or Conflict of Natural Resource Use in Ecoregion Areas

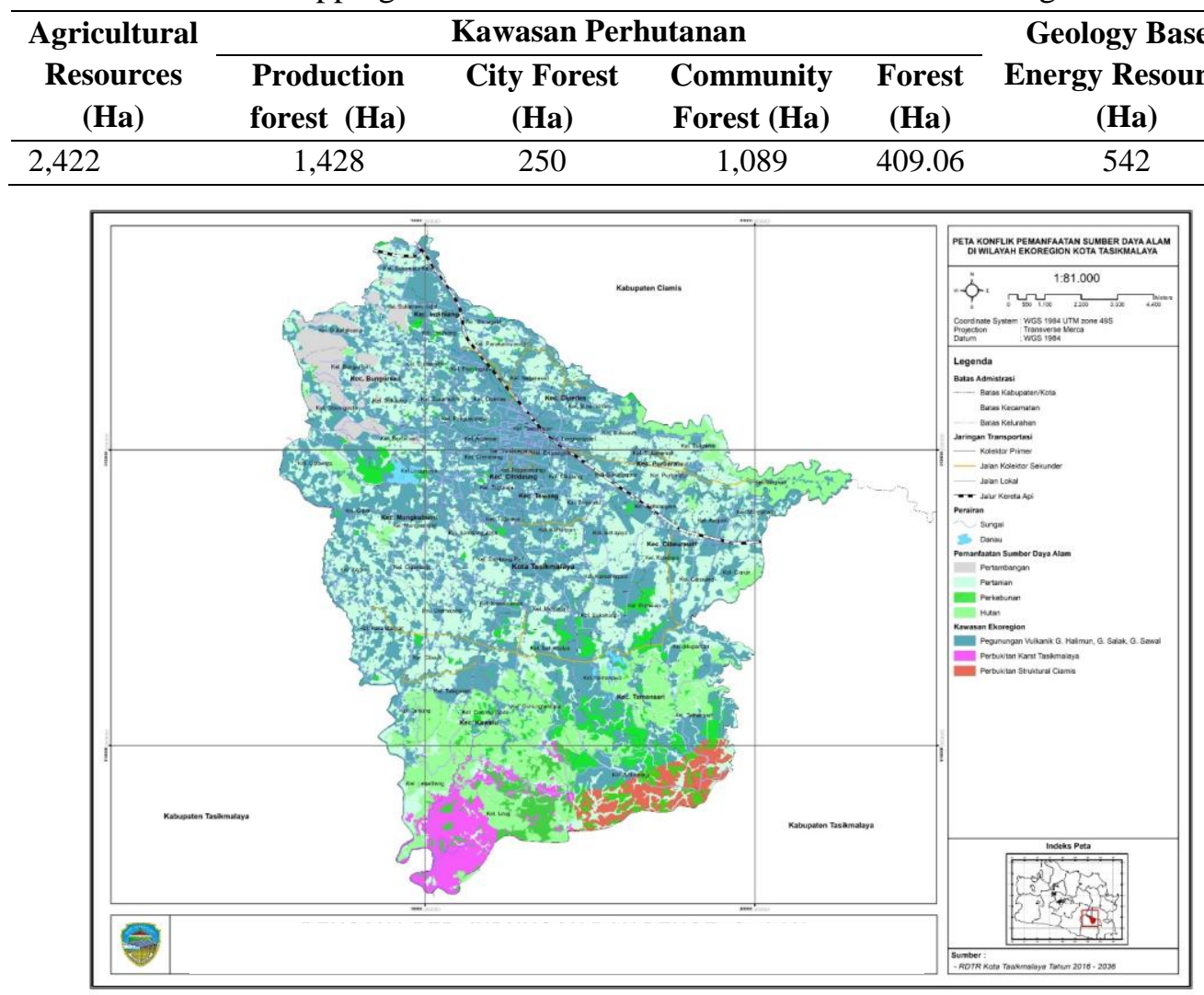

Figure 2. Map of Natural Resources Utilization Conflict 
Based on the identification of spatial use conflicts between natural resources, several possible conflict resolution options are presented in the table below in order to maintain ecosystem services and functions in the ecoregion area. The options offered are so that in the future the use of forests and productive land, especially food and those with geological natural resources, can be utilized properly and maximally and there are trade-offs for forest reuse for the future. The options offered can be seen in the Table 4.

Table 4. Options for Revolution of Spatial Conflict between Natural Resources

\begin{tabular}{|c|c|c|c|c|c|}
\hline \multirow{2}{*}{$\begin{array}{c}\text { Agricultural } \\
\text { Resources }\end{array}$} & \multicolumn{3}{|c|}{ Forestry Area } & \multirow[b]{2}{*}{ Forest } & \multirow{2}{*}{$\begin{array}{c}\text { Geology } \\
\text { Based Energy } \\
\text { Resources }\end{array}$} \\
\hline & Production forest & $\begin{array}{c}\text { City } \\
\text { Forest }\end{array}$ & $\begin{array}{c}\text { Community } \\
\text { Forest }\end{array}$ & & \\
\hline Rice Fields & $\begin{array}{l}\text { Permitted by an area } \\
\text { exchange } \\
\text { mechanism; } \\
\text { Permitted for rain- } \\
\text { fed rice fields by } \\
\text { including it in the } \\
\text { production forest } \\
\text { rehabilitation } \\
\text { process. }\end{array}$ & $\begin{array}{l}\text { Not } \\
\text { allowed }\end{array}$ & $\begin{array}{l}\text { Permitted for } \\
\text { rainfed lowland } \\
\text { rice fields by } \\
\text { participating in } \\
\text { the process of } \\
\text { production } \\
\text { forest } \\
\text { rehabilitation } \\
\text { process }\end{array}$ & $\begin{array}{l}\text { Permitted for } \\
\text { rainfed lowland } \\
\text { rice fields by } \\
\text { participating in } \\
\text { the process of } \\
\text { production } \\
\text { forest } \\
\text { rehabilitation } \\
\text { process }\end{array}$ & Not allowed \\
\hline $\begin{array}{l}\text { Allocation of } \\
\text { Rice Paddy } \\
\text { Land } \\
\text { Provision }\end{array}$ & $\begin{array}{l}\text { Permitted by an area } \\
\text { exchange } \\
\text { mechanism }\end{array}$ & $\begin{array}{l}\text { Not } \\
\text { allowed }\end{array}$ & $\begin{array}{l}\text { Permitted by an } \\
\text { area exchange } \\
\text { mechanism }\end{array}$ & $\begin{array}{l}\text { Permitted by an } \\
\text { area exchange } \\
\text { mechanism }\end{array}$ & $\begin{array}{l}\text { Determination } \\
\text { of Geology } \\
\text { Based Energy } \\
\text { Resources } \\
\text { must first } \\
\text { consider the } \\
\text { status of the } \\
\text { Allocation of } \\
\text { Rice Paddy } \\
\text { Land Provision }\end{array}$ \\
\hline $\begin{array}{l}\text { Geology } \\
\text { Based } \\
\text { Energy } \\
\text { Resources }\end{array}$ & $\begin{array}{l}\text { Permitted for non- } \\
\text { forest land cover } \\
\text { and unproductive } \\
\text { land for forest } \\
\text { exploitation }\end{array}$ & $\begin{array}{l}\text { Not } \\
\text { allowed }\end{array}$ & $\begin{array}{l}\text { Permitted for } \\
\text { non-forest land } \\
\text { cover and } \\
\text { unproductive } \\
\text { land for forest } \\
\text { exploitation }\end{array}$ & $\begin{array}{l}\text { Permitted for } \\
\text { non-forest land } \\
\text { cover and } \\
\text { unproductive } \\
\text { land for forest } \\
\text { exploitation }\end{array}$ & \\
\hline
\end{tabular}

Formulation of Tasikmalaya City Ecoregion Protection Strategy

1. Balancing the pace of development with the carrying capacity and carrying capacity of the environment, with the following objectives: a. Synchronization of RTRW with RPPLH for the City of Tasikmalaya

b. Guaranteed availability of water for life and sustainable development. 
c. Guaranteed environmental support for sustainable food production.

d. Guaranteed utilization and reserve of natural resources in a sustainable and socially just manner.

2. Improve the quality of the environment and protect the function of environmental sustainability with the following goals:

a. Reduced pressure on ecoregions and water-producing and regulating ecosystems.

b. Less pressure on ecoregions and foodproducing ecosystems.

c. Reducing the level of soil and air environmental pollution.

d. Reduced levels of damage to forest and karst ecosystems.

e. The area and function of areas with genetic resources and habitat for high species are maintained.

3. Strengthen governance and government and community institutions for environmental control, monitoring and utilization and preservation. With the following objectives:

a. Availability of mechanisms for controlling the use of natural resources and the environment through various instruments.

b. Availability of systems and instruments for monitoring and preserving the environment with measurable indicators.

c. Guaranteed efficient use of natural resources and the environment for longterm use. d. Increased cooperation between administrative areas in controlling, monitoring as well as utilizing and preserving natural resources and the environment.

e. Increased participation of the public and private parties in environmental protection and management.

4. Increase resilience and preparedness in the face of disasters and the impacts of climate change. With the following objectives:

a. The reduced level of vulnerability and risk due to the negative impacts of climate change.

b. Increased capacity and community preparedness in facing the negative impacts of climate change.

c. Availability of green infrastructure to minimize the impact of climate change.

d. Development of green cities and disaster resilient cities.

e. Development of a low emission public transportation system.

f. Development of new and renewable energy sources.

Indicators of Ecoregion Protection and Management in Tasikmalaya City based on $5 \mathrm{~K}$ (Consistency, Consultation Coordination, Capacity and Sustainability)

Table 5 shows the protection and management of ecoregions in Tasikmalaya City based on consistency, coordination, consultation, capacity and sustainability. 
Table 4. Protection and Management of Ecoregions in Tasikmalaya City based on 5K (Consistency, Coordination, Consultation, Capacity and Sustainability

\begin{tabular}{|c|c|c|}
\hline No & $\begin{array}{c}\text { Evaluation } \\
\text { Aspects }\end{array}$ & Indicator \\
\hline 1 & Consistency & $\begin{array}{l}\text { - There is consistency of planning in Environmental Protection and } \\
\text { Management Plan with the implementation carried out by } \\
\text { government agencies. } \\
\text { - Quantity of programs in Environmental Protection and Management } \\
\text { Plan listed in government agency planning. } \\
\text { There is a match between the planning in Environmental Protection } \\
\text { and Management Plan and planning in each Environmental } \\
\text { Protection and Management Plan implementing institution. }\end{array}$ \\
\hline 2 & Coordination & $\begin{array}{l}\text { - The realization of a better and more directed level of planning } \\
\text { coordination among various agencies implementing environmental } \\
\text { protection and management involved in the Environmental } \\
\text { Protection and Management Plan policies. } \\
\text { - The realization of a better and more concrete level of budgeting } \\
\text { coordination among various agencies implementing environmental } \\
\text { protection and management. } \\
\text { The realization of a more synchronous and more harmonious level } \\
\text { of implementation coordination among various implementing } \\
\text { agencies for environmental protection and management. }\end{array}$ \\
\hline 3 & Consultation & $\begin{array}{l}\text { - There is community participation by submitting input, suggestions, } \\
\text { criticism and complaints about the implementation of policies in the } \\
\text { Environmental Protection and Management Plan carried out by } \\
\text { various implementing agencies } \\
\text { The existence of communication and information media for the } \\
\text { public to convey aspirations in an effort to oversee and improve the } \\
\text { implementation of the Environmental Protection and Management } \\
\text { Plan policy. } \\
\text { Availability and easy access to public information through } \\
\text { electronic and print media, websites and internet, public complaint } \\
\text { post boxes in order to encourage dissemination of the } \\
\text { implementation of policies in the Environmental Protection and } \\
\text { Management Plan. }\end{array}$ \\
\hline 4 & Capacity & $\begin{array}{l}\text { - The realization of adequate implementing institutional capacity in } \\
\text { implementing Environmental Protection and Management Plan } \\
\text { policies. } \\
\text { - The realization of human resource capacity related to personnel } \\
\text { involved in the process of implementing environmental protection } \\
\text { and management programs. } \\
\text { - Fulfilled sufficient funding capacity to be used in environmental }\end{array}$ \\
\hline
\end{tabular}




\begin{tabular}{|c|c|c|}
\hline No & $\begin{array}{c}\text { Evaluation } \\
\text { Aspects }\end{array}$ & Indicator \\
\hline & & $\begin{array}{l}\text { protection and management programs. } \\
\text { There are more diverse and mutually supportive sources of funding } \\
\text { for each institution implementing Environmental Protection and } \\
\text { Management Plan policies. } \\
\text { - Fulfilled disaster risk reduction executive capacity in terms of } \\
\text { control and supervision. }\end{array}$ \\
\hline 5 & Sustainability & $\begin{array}{l}\text { - Arrangement of various policies for maintenance and management } \\
\text { in the medium and long term } \\
\text { - The creation of an exit management program and activity strategy } \\
\text { for the implementers of environmental protection and management } \\
\text { policies. } \\
\text { - Various policy inputs were formulated for the preparation of the } \\
\text { Environmental Protection and Management Plan document for the } \\
\text { next period. }\end{array}$ \\
\hline
\end{tabular}

\section{Conclusion}

Based on the description and explanation of the results of this study, it can be concluded as follows:

- The various program directives and milestones listed in this document need to be elaborated in more detail, particularly in preparing programs and activities for environmental protection and management to achieve predetermined targets.

- The implementation of protection and management of the Tasikmalaya City Ecoregion requires active involvement and participation of all stakeholders, not only the city government and its involved institutions, but also requires active involvement from the community. The active involvement of all stakeholders is very important starting from the planning process, conduct monitoring the implementation of policies.

- The projected population growth over the next 30 years will have an impact on increasing economic activity that has the potential to put pressure on the ecoregion.

\section{References}

Bailey, R.G. (2005). Identifiying Ecoregion Boundaries. Environmental Management. Vol. 34(Suppl.1), S14-S26.

Carr, E.R., Wingard, P.M., Yorty, S.C., Thompson, M.C., Jensen, N.K., Roberson, J. (2007) Applying DPSIR to Sustainable Development. International Journal of Sustainable Development \& World Ecology. Vol 14, 543-555.

Magsi, H., Torre, A., Liu, H., Sheikh, M.J. (2017). Landuse Conflicts in the Developing Countries: Proximate Driving Force and Preventive Measure. Pakistan Development Review. Vol 56(1), 19-30.

Ramadanta, A., Basri, I.S. (2011). Pendekatan Ecoregion dalam Pengembangan Kawasan Wisata Studi Kasus Penataan Kawasan Wisata Danau Poso. Jurnal “ruang”. Vol. 3(1), 1-13.

Subekti, S. (2016). Rencana Perlindungan dan Pengelolaan Hidup Provinsi Kalimantan Selatan. Jurnal Neo Tenika. Vol. 2(1), 1726. 
Wang, Z., Zou, J., Loaiciga, H., Guo, H., Hong, S. (2015). A DPSIR Model for Ecological Security Assessment through Indicator Screening: A Case Study at
Dainchi Lake in China. Plos One. DOI:10.1371/journal.pone.0131732 